\title{
真空技術調査部会の発足と活動報告
}

\author{
本田融*1
}

\section{Activity Report of Vacuum Science and Technology Investigation Group of Vacuum Society of Japan}

\author{
Tohru HONDA*1 \\ ${ }^{* 1}$ Accelerator Laboratory, High Energy Accelerator Research Organization (KEK), 1-1 Oho, Tsukuba-shi, Ibaraki 305-0801, Japan
}

(Received January 13, 2016, Accepted January 25, 2016)

\section{1. 真空技術調査部会発足の経緯}

「『真空を作る』時代から，『真空を使う』時代となって久 しい. 基礎となる真空技術（真空排気技術，真空計測技術， 真空部品製造技術）は多岐に発展しているが，近年は機器が システム化されているが故に，基盤となる真空技術の展開に ついては目にする機会が少なくなってきている，本調査部会 では, 真空機器関連技術の近年の状況を幅広く調査し，また 技術の歴史もふりかえり，研究会等の啓発活動を通して次世 代真空技術の発展に寄与する」.

以上のような設立趣意を掲げて日本真空学会の 3 つ目の 部会として2014年 7 月に真空技術調査部会が新しく発足し ました．理事会で推薦をいただくなどして，立上げメンバー として大学, 研究所関係から本田融 (部会長, KEK), 道園 真一郎 (副部会長, KEK), 松本益明 (学芸大), 池田暁彦 (東大), 中村健 (産総研), 齊藤芳男 (東大), 法人関係より 伊尾木公裕 (トヤマ), 高宮祐二 (大亜真空), 稲吉さかえ (アルバック), 中村恵 (キヤノンアネルバ), 田口竜大（島 津製作所), 川村毅 (荏原製作所), 原口孝之（大阪真空） (順不同）の真空計測から真空ポンプ，また装置開発などを 専門とされるバラエティーに富んだ皆さんに部会に参加して いただきました．2015年には山本将博（KEK）, 西脇みちる (KEK) のお 2 人も新しく加わってくれました.

2014年半ばから2015年にかけて計 7 回の部会を開催し, 部会メンバーによる技術調査報告やゲストの方に情報提供を いただいたりしております。以下にこれまでの活動の内容を 簡単にご報告させていただきます.

\section{2. これまでの活動内容}

真空機器関連技術の幅広い調査というテーマを与えられ手 探りで活動を開始したところですが，手始めにターボ分子ポ ンプやドライポンプ, 材料のガス放出データなどについて主 として学術雑誌の文献情報を収集するなどして, 調査を進め ているところです.

ターボ分子ポンプのルーツは W. Gaede が “The Molecular Air Pump” と題する1913年のドイツ語の論文1)に発表し

*1 真空技術調査部会長, 高エネルギ一加速器研究機構加速器研究 施設（干305-0801 茨城県つくば市大穂 1-1)

E-mail: tohru.honda@kek.jp
た世界初の“分子ポンプ”にあことは良く知られています。 この論文では分子ポンプを試作して排気実験をした結果と， 排気機構の理論的な考察が詳しく記されています. その後 1923年の M. Holweck ${ }^{2}$ による “ドラム型” 分子ポンプ, 1944年の M. Siegbahn ${ }^{3}$ による “ディスク型” 分子ポンプの 開発などが報告されていますが，実用的な高真空ポンプの主 役は長い間 W. Gaede 自身が1915年に発明した拡散ポンプ でありました。ちなみに Gaede の分子ポンプは到達圧力こ そ10-6 torr と高真空を実現していますが，排気速度は $11 / \mathrm{s}$ 程度に過ぎなかったようです．30年後の Siegbahn らのディ スク型分子ポンプは $60 \mathrm{~cm}$ 程度の大口径のポンプも製作さ れ排気速度は $1001 / \mathrm{s}$ 級に達して抢り, 初期の分子ポンプの 中では最も成功を収めたと言わ机ています。

現在の “ターボ分子ポンプ” は Pfeiffer 社のW. Becker によって開発され1958年に市販された横型モデルに始まり ます．Becker は1958年にベルギーで開催された 1st International Vacuum Conference (IVC) でも“A New Molecular Pump” と題して発表を行っています4). 現在一般的となっ た縦型ターボ分子ポンプの文献は1972年の Leybold 社の K. H. Mirgel ${ }^{5)}$ による報告あたりが最初です。当時すでに日本 でも大阪真空では縦型の「軸流分子ポンプ」の開発が進めら れており, 国産初のターボ分子ポンプ T650は1971年に完成 していました。澤田雅先生を中心として発明された「複合分 子ポンプ」は, やはり大阪真空で1983年に試作機が完成し たそうです。

1975年に Leybold 社は磁気浮上軸受のターボ分子ポンプ を世界に先駆けて発売しましたが信頼性などの問題があり， あまり評判は芳しくなかったようです。磁気浮上型ターボ分 子ポンプはその後1984年に発売されたセイコー精機（当時） のSTP-300以降, 日本で大きく発展し, 成功を収めたこと は皆さんも良くご承知のことと思います。

現状，ターボ分子ポンプは大流量，高压縮比など様々な用 途に対応した発展を遂げています。最近学術雑誌に現れる ターボ分子ポンプをタイトルに含む論文は, 高度なシミュ レーションに基づく開発設計が主となっています.

ターボ分子ポンプに続いてその市場を広げつつあるドライ ポンプについても文献情報を中心に調查を行ってみました。 ドライポンプ製品が初めて登場したのは，1984年に発売さ れた日本の宇野沢組の多段 Roots ポンプであるとも1985年 
のエドワーズ社 Roots/claw 型ポンプ6) とも言われていま す. それ以降急速に発展を遂げ粗排気用真空ポンプとして実 用化されているドライ真空ポンプはほとんどが Roots 型, scroll 型, claw 型, screw 型, piston 型, diaphragm 型など の “容積移送式”です.

claw 型ポンプ（真空ポンプに限らず）の元祖である Northey 社の Web ページ7)には広範囲にわたる用途や動作 原理を解説するパンフレットが掲載されています.

“運動量移送式”としては大気圧ターボ分子ポンプ8), ター ボ型ドライポンプ9)などの文献報告が見られましたが，製品 として成功をした例はなさそうです。

ドライポンプでは, 到達圧力や排気速度などの性能の限界 を決める要因がぞこにあるのかが性能改善の重要な手掛かり になると思います. screw 型や scroll 型の性能の限界を議論 する文献10,11) が真空誌に発表されています.

ドライポンプについてはターボ分子ポンプに比べても, 学 術雑誌に掲載された論文の数は少なめで, 製品開発に携わっ た企業の技術資料が重要な記録となると思われます。

ガス放出データに関しては, 現在真空学会が監修しコロナ 社で編纂が進められている “真空科学ハンドブック”の記事 作成に向けて数多く多くの文献調査を行った結果を稲吉さん から提供していただきました。

“真空科学ハンドブック”には, ステンレス鋼, アルミニ ウム合金, チタン, 銅その他の材料について「大気圧からの 排気」と「ベーキング後のガス放出率」に分けてデータを整 理した表やグラフが多数掲載されをす．出版をぜひご期待く ださい．部会には調査に用いた参考文献のリストも提供いた だきました。

また真空技術調査部会ではゲストをお招きしてお話を伺う 試みも行っています. 先日は真空学会の規格・標準委員会で も活躍されているバックス・エスイーブイの黒河内智氏から 「公的規格は標準化のガイドたり得るか」と題し，いわゆる ICF フランジの ISO 規格の制定の経緯や現状について解説 をしていただきました。

\section{3. 今後の活動方針について}

現在, 調査をした文献のリストや発表ファイルなどを部会 内の Web（ブログ）ページに整理して蓄積をしている段階 です．今後真空学会の会員の皆様にとって見やすく役に立つ 形で，できるだけ早く公開をしたいと考えています．公開の 方法は真空学会のホームページにアップロードし随時更新を していく形式がふさわしいと考えています. 広報委員会の皆 様とも相談をしながら進めて行きたいと思っています. 部会 のWebページ（形式は全く整っていないのですが）にアク セスをしてみたいと思われる方がもしありましたら, 真空技 術調査部会か真空学会事務局までぜひご連絡ください.

調査としては, 前項に報告をした項目について引き続き情 報を蓄積し現状の把握と将来展望を探っていくほか, 真空計 測 (全圧, 分圧), 気体分子のモンテカルロシミュレーショ ン, 非蒸発型ゲッターポンプ, 表面処理などのテーマも, 調 査対象として参りたいと考えています.

まだまだ活動は暗中模索の状態が続いておりますが，会員 の皆様が興味を持ち，またお役にたてるような情報を取集，

整理することを目指して取り組んで行きたいと思っていま す、ご意見，アドバイス，また活動へのご参加を広く歓迎い たします。どうぞ遠慮なく打知らせください.よろしく㹉 いします。

\section{〔文献〕}

1) W. Gaede: Annl. Phys., 41 (1913) 337.

2) M. Holweck: Comptes Rendus, 177 (1923) 43.

3) M. Siegbahn: Arkiv for Matematik, Astronomi och Fysik, 30B (1944) 17.

4) W. Becker: Advances in Vac. Sci. Technol., 1 (1960) 173.

5) K. H. Mirgel: J. Vac. Sci. Technol., 9 (1972) 408.

6) H. Wycliffe: J. Vac. Sci. Technol. A, 5 (1987) 2608.

7) Northey Technologies LTD, https://vacsocjpn.files.wordpress. com/2015/07/northey-booklet.pdf (Last accessed: 2016-0111).

8）川㠃裕之, 小神野宏明 : エバラ時報, 225 (2009-10) 37.

9) M. Mase, I. Gyobu, T. Nagaoka and S. Ueda: Shinku, 33 (1990) 627.

10) T. Sawada and T. Ohbayashi: Shinku, 49 (2006) 460.

11) I. Akutsu and G. Horikoshi: Shinku, 42 (1999) 663. 